\title{
The Role of Gold Dinar And Silver Dirham User Entrepreneurship Community in Dinar-Dirham Replacement Equipment As a Medium of Exchange
}

\author{
Srie Nuning Mulatsih, Aisyah Ratnasari, and Dadang Saepuloh
}

Universitas Islam SYekh-Yusuf

\section{Abstract}

The issue of going back to use gold dinar and silver dirham as currency has become warmly discussion since the ASEAN currency depreciation crisis in 1997/998 and the global economic crisis going on nowadays. Until now, there is still no one ideal mechanism implemented globally the use of gold dinar and silver dirham. Even has still not implemented globally yet but there are efforts for some of communities to implemented them in daily life, transaction, like the community of the entrepreneurs

Corresponding Author: Srie Nuning Mulatsih nuningpurwanto@unis.ac.id

Received: 10 February 2019 Accepted: 14 March 2019 Published: 28 March 2019

Publishing services provided by Knowledge E

(c) Srie Nuning Mulatsih et al. This article is distributed under the terms of the Creative Commons Attribution License, which permits unrestricted use and redistribution provided that the original author and source are credited.

Selection and Peer-review under the responsibility of the ICIEBP Conference Committee. community of dinar dirham users. The question arose: will gold dinar and silver dirham can be used back as mediumof exchange in current economy? So, this study aims to examine the role of the entrepreneurs community of dinar-dirham users in effort implementation of dinar dirham as medium of exchange. This is quantitative study going by the strategy of the field research and by using the variables, economic aspects and religious aspects. This study also used library research approach. The result of this research with purposive sampling method at user community gold dinars and silver dirhams as medium of exchange effort religion aspects is dominant factor than economical factor and the research shows that the role of the entrepreneurs community of dinar dirham users in effort implementation of them as currency are quite suitable, because of inadequate awareness reforms and lack political will (consensus from other nations to use gold dinar and silver dirham as money) and the ignorance of people about the function of gold dinar and silver dirham as medium of Exchange.

Keywords: Gold dinar, Silver dirham, Entrepreneurs Community of Dinar Dirham Users, Economic Crisis

\section{Introduction}

Money in its various forms as a means of exchange of trade has been known thousands of years ago as in the history of Ancient Egypt around 4000 BC-2000 BC, but before people know money as a means of exchange of trade, although people barter, exchange 
In its more standard form of money in the form of gold and silver was introduced by Julius Caesar from Rome around AD 46 and valid in the European world for about 1250 years. Until the year 1204. In other parts of the world in the Islamic world, gold and silver money known as Dinar Dirham is also used since the beginning of Islam both in muamalah and worship activities such as zakat and diyat (fines) until the end of the Turkish emporium 1924.

Gold and silver were used because they had the content and value of the essence in globally universal, applicable in all parts of the world..By the times, the capitalists who make gold and silver not merely as a medium of exchange but also as a trade of commodity Replacing the role of gold and silver as a medium of exchange. Until slowly gold dinars and silver dirhams replaced with fiat money (paper money). The banknotes recognized by many capitalists can solve the problem, facilitating the transaction can not solve the problem, because it does not have a standard that is recognized by the whole world. The value exists because it was held by those who have the authority to issue banknotes different from gold and silver which have value attached to the object.

The above circumstances led to the idea of reusing gold dinars and silver dirhams since several countries in Southeast Asia and some other countries experienced economic crisis in 1997/1998 and in recent years. Gold dinars and silver dirhams are believed to overcome this, referring to the idea of returning the supply of gold to the real money system.

The idea that was initiated by some economists, Islam is not easy to implement given the world economic system is interrelated and affect. Nevertheless it is not impossible to restore the function of gold dinars and silver dirhams into a medium of exchange in transactions, bermuamalah, especially in transactions like this there is a value of worship in it, taught by Rasulullah Muhammad SAW, and some verses of Al-qur'an also explain the function Gold and silver.

Of this concern, some circles who have a concern to restore the function of the gold dinars and silver dirhams form a community called the User Community Dinar Dirham. Members of this community are individuals and institutions who care about bermuamalah with dinar-dirham.

Given the above exposure, the authors are interested in researching on how THE ROLE OF DINAR-DIRHAM USER ENTREPRENEURSHIP COMMUNITY IN DINARDIRHAM REPLACEMENT EQUIPMENT AS A MEDIUM OF EXCHANGE. 


\subsection{Problem formulation}

Based on the background of problems that have been described earlier, it can be defined some of the problems encountered in the use of dinar dirham as a medium of exchange among the community of entrepreneurs dinar dirham users as follows:

-What are the economic factors that play a role in the use of dinar dirhams among the entrepreneur community of dinar dirham users as a medium of exchange?

- What are the religious factors that play a role in the use of dinar dirhams among the entrepreneurial community of dinar dirhams as a medium of exchange?

- Does the role of entrepreneur community of dinar dirham users have an effect on the application of dinar dirhams as a means of exchange?

\section{Literature Review}

\subsection{Understanding of Dinar and Dirham}

Money in its various forms as a means of trade exchange has been known thousands of years ago as in the history of ancient Egypt around 4000SM-2000SM. In its standard form of gold and silver money was introduced by Julius Caesar from Rome around 46SM. In the rest of the world in the Islamic world, gold and silver coins are known by the name of Dinar Dirham.

Currency Dinar and Dirham origin is the original currency of Roman and Persian which in ancient times are both superpowers in the world. The word dinar in Arabic and Persian is derived from the word "denarius" Roman currency. However, "denarius" is different from the 'golden dinar' of Islam.

From another perspective, more philosophical, the dinar currency called 'Dinar' comes from the words 'Din' and 'Nar'. Din means religion and Nar means hell. As for the meaning is who takes it by his right

Weighing then it is his religion and on the contrary the one who takes it without right then it is the fire of hell. (IbnKathir's commentary 2/60).

In general, Dinar means gold currency 71.5 sya'ir or approximately 4.68 grams, gold coins weighing 4.25 grams and 22 carat content (91.7\%). Dinar is also the basic unit of currency Abu Dhabi, Algeria, Bahrain, Jordan, Libya, South Yemen, Tunisia, Kuwait, Iraq which is different from the dinar as gold coins. 
Dirham or dirhm is a currency unit in some Arab countries also Tajikistan. The former was associated with the mass dram units of the Ottomanand Persian empires. This name is derived from the Greek currency, drachma or bidrachm. In Roman times,

As with the use of drachmas, dirhem is used as a unit of weight across North Africa, the Middle East and Persia with different values. In its development Dirham is a silver currency weighing 2,295 grams. Another opinion states that the weight of 1 dirham equal to $7 / 10$ dinar or equal to 2.975 grams.

\subsection{Dinar-Dirham in Islamic view}

In Islamic Jurisprudence, gold and silver coins are known as an essential means of exchange (real) while copper or bronze money is known as fulus and is a means of exchange by agreement. Fulus is closer to the nature of the banknotes we know today, because they do not have intrinsic value (value inherent in the physical) of the exchange rate.

The function of money in the Islamic economic perspective is limited to money as a means of exchange of goods and services. Islam prohibits the accumulation of money and makes money as a commodity, because the hoarding of money means slowing the velocity of money. This means minimizing the occurrence of transactions, so the economy becomes sluggish. Islam forbids usury and rejects all kinds of artificial transactions, as happened in the money market or the capital market today.

The use of dinars and dirhams as a means of exchange of payments and economic transactions activities is based on the following:

- The Qur'an and As Sunnah mention wealth and wealth with the terms gold and silver (dinar and dirham).

- Efforts to uphold the pillars of Islam is to pay zakat and enforce Islamic law.

A Muslim who possesses gold, money and other possessions who have attained nishab (weight size) worth of gold 20 dinars shall pay zakat.

- Gold money is universal and acceptable to all parties because the material is gold and relatively more difficult to forge. Gold money has certain colors, levels and strengths that can not be made from other metals.

- Gold money can be used as a savings tool whose value is relatively more stable. With gold money, its value does not experience sharp fluctuations, because the nominal value is equal to its intrinsic value. 
In Islamic economics, the function of money is recognized only as a medium of exchange and unit of account. Money itself does not provide usefulness / benefit but the function of money that provides usability.A Muslim who possesses gold, money and other possessions who have attained nishab (weight size) worth of gold 20 dinars shall pay zakat.

- Gold money is universal and acceptable to all parties because the material is gold and relatively more difficult to forge. Gold money has certain colors, levels and strengths that can not be made from other metals.

- Gold money can be used as a savings tool whose value is relatively more stable. With gold money, its value does not experience sharp fluctuations, because the nominal value is equal to its intrinsic value.

In Islamic economics, the function of money is recognized only as a medium of exchange and unit of account. Money itself does not provide usefulness / benefit but the function of money that provides usability.

\subsection{Al-qur'an verses relating to Dinar-Dirham}

Long before the West used the money in every transaction, the Islamic world was familiar with the means of exchange and measurement of that value, even the Qur'an explicitly stated the value measuring instruments in the form of gold and silver expressed as dinars and dirhams.

\subsubsection{Dinar}

Understanding / usage of Dinar is contained in the Qur'an Surah Ali Imran verse 75

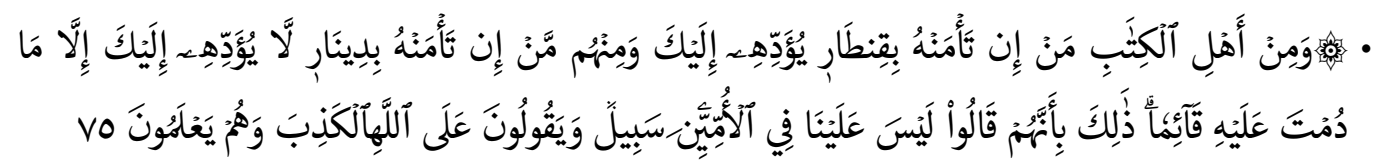

- 75. "among the scribes there are those who, if you entrust to him a great deal of treasure, return it unto you; And among them is someone who, if you entrust him with a denarius, will not return it to you unless you always charge him. That is because they say: "There is no sin for Us against the ummah [206] They say a lie against Allah, but they know.[206] What they mean by the Ummi people in this verse is Arabs 


\subsubsection{Dirham}

The usage / understanding of Dirham is contained in the Qur'an of Surah Yusuf verse 20

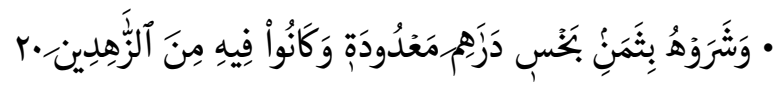

- 20. And they sell Joseph for a bargain price, that is a few dirhams only, and they feel uninterested in Yusuf [747]

\subsubsection{Gold, Silver}

The use of gold and silver as a medium of exchange is contained in the Qur'anic chapter of At-Taubah verse34

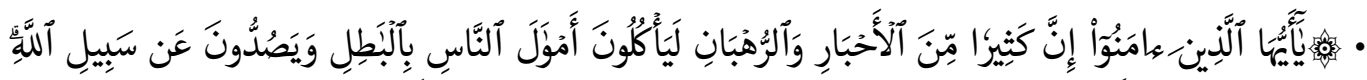

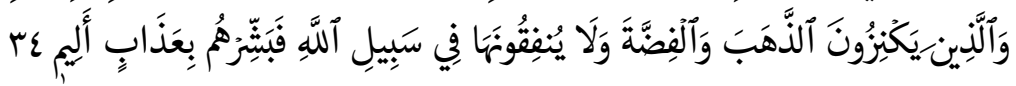

- 34. "O ye who believe! Truly, most of the Jewish people and the Christian monks actually eat the treasures of men by the way of vanity and they hinder (man) from the way of Allah. And those who store gold and silver and spend it not in the way of Allah. Tell them (that they will get) a painful punishment,

\subsubsection{Waraq or silver pricing}

The use of waraq or silver apparatus as a medium of exchange is contained in sura Al Kahfi verse 19

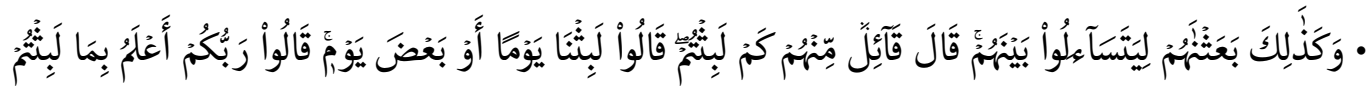

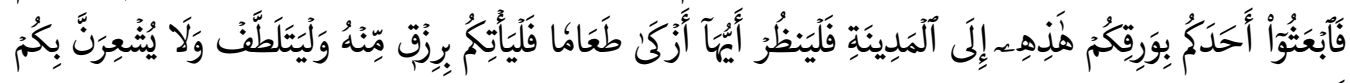

- 19. And thus did We wake them up so that they might question each other among themselves. One of them said: how long have you been here? "They replied:" We are (here) a day or half day. "Say (another):" Your Lord knows better how long you have been (here). Then send one of you to go into the city with your silver money, and let him see what better food is. Then let it bring the food to you, and let it behave in gentleness and never tell you Anyone.

E. Commercial merchandise commonly used as a tool of exchange is contained in the Qur'an verse of Surah Yusuf verse 88 




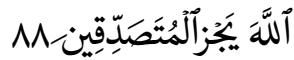

- 88. And when they went into Joseph they said: "Al Aziz, We and Our family have been afflicted with misery, and We have come with unworthy goods, And complete the garment for Us, and give charity to Us, Allah rewards those who give charity".

\section{Research Methodology}

\subsection{Research methods}

This research is based on the level of explanation using descriptive method of research that is characteristic of describing the existence of variables (research objects) on the question of the existence of variables. In this research the variable in question is the use of dinar dirham as a medium of exchange in the community environment of dinar dirham users in muamalah.

\subsubsection{Data collection technique}

This research was conducted by collecting data in the form of:

- Observation / Observation

The writer / researcher directly observe the economic activities conducted by the Community, such as the activities of Muamalah School which is done several weeks.

- Interview

Authors / researchers conducted direct interviews to activist muamalah activities that use Dinar Dirham as a means of transaction.

- Questionnaire

The writer / researcher distributes questionnaire / questionnaire regarding the role of Community in the effort of applying Dinar, Dirham as a medium of exchange.

- Documentation

This technique is done to support theoretical or conceptual ideas about research variables, in this case the reference books, documents and articles that have been there before and there is relevance to the problem will be solved. 
- Sampling technique

The population used in this study were the Community while the samples used random sampling technique with Purposive Sampling method. Because sampling from the population was done randomly but paid attention to the same purpose of the sample.

\section{Conclusions}

In order to expand the use of gold dinars and silver dirhams in practical activities in practical day -to-day a real intiation has begun in the form of network of users of gold dinar and silver dirhams. This intiative is called The Network of Entrepreneurs DinarDirham Nusantara (JAWARA- www.jawaradinar.com). Jawara was initiated in Bandung by Amirat Indonesia and Wakalalnduk Nusantara (WIN) and witness by number of dinar dirham users who gathered on SauqiWakala on January 10, 2009. The main mission of Jawara is to Develop the practice trade transaction (product and services) Probably in the community nationally and internationally.

Jawara is an open network for all parties, individuals and institutions without differentiating the types of business and services of real sector, race, ethnicity, and the area of its activities. Intiative of Jawara will complement the use gold dinars - silver dirhams which limited as investment but use to paying zakat, infak, sedekah (ZIS) and Wakaf medium of exchange free riba and inflation, mahar.

Jawara's initial program was to revive trade routes, charitable activities, direct transactions using gold dinars and silver dirhams, and set up open markets. To facilitate the transaction along with the establishment of Jawara, also presented m-Badar (Payment Barter Voluntary Dinar-Dirham Electronic), which has been accessed at http: //wakalanusantara.com/. In the early stages m-Badar is provided as an information service of the gold dinar exchange rate and silver dirham.

Now renamed the User Community / Dinar Dirham Users as a medium of exchange. The users of Dinar Dirham are combination of entrepreneurs, traders, producers and service providers who use gold dinars and silver dirhams as a means of exchange in daily trading activities its called muamalah market.

Monthly activity is always held by user community gold dinars and silver dirhams as medium of exchange at Tanah BaruBejiDepokJawa Barat. The community really concern on the sunnah, do transaction using dinar and dirham. 
The m-Badar facility is a tool for transactions between Dinar Dirham users, both in personal transactions and payment of services and corporate trading. The electronic payment system is backed up 100\% with gold dinars and silver dirham in this physical form, also connected with e-dinar (http: www.e-dinar.com), provider of international electronic Dinar Dirham payment system that has been operating since year 2000 . Thus the users of gold dinars and silver dirham in Indonesia will be connected with users of gold dinars and silver dirhams around the world. With m-Badar and e-Dinar, Dinar and Dirham transactions do not always have to be done physically until the hassles that may arise in various situations can be resolved.

But now The m- Badar facility is on recovery caused by the increasing of wakala and muamalah market in Indonesia. A long time ago just Cirebon Residen whose printed gold dinar. A few day ago MangkuNegeriTanjungPura Darussalam whose printed silver dirham.Recently a Fuqara from Tanjungpinang, Bintan Riau Islands who have been doing business through off line began to increase their marketing area through online. Through the Shop Book IImi account offers several premium products, namely instant cooking and healthy broth, Halal and without the use of Mono Sodium Glutamate [MSG]. Tokollmi Salted Eggs can be paid with SilverDirhamEspecially for Tanjungpiang area, Tokollmi also offers local products for home industry salted eggs which are suitable and suitable. Other good news, all products can be paid with Silver Dirham, sunnah money with the basis of pleasure and pleasure.

The result of this research with purposive sampling method at user community gold dinars and silver dirhams as medium of exchange effort religion aspects is dominant factor than economical factor. This is not in line with research conducted by SrieNuningMulatsiheith title of analysis of factors that effect the use of Dinar-Dirham as currency where economic factors are more dominant than religious factor. User community gold dinars and silver dirhams as the medium of exchange know and understand the basic of doing transaction to avoid usury formuamalah activities get blessing from Allah SWT because in a accordance with the Qur"an and Sunnah.

[1] Al-Quran danTerjemahan. 2002, Jakarta: Departemen Agama RI.

[2] Adiwarman K, A, Ir, Sejarah Pemikiran Islam, EdisiKetiga, RajawaliPers, Jakarta, 2010

[3] Adiwarman K, A, Ir, EkonomiMakrolslami, EdisiKedua, RajawaliPers, Jakarta,2008

[4] Ahmad IfhamSolihin, BukuPintarEkonomi Syariah, Gramedia, Jakarta, 2010

[5] Mohamad Hidayat, An Introduction To The Sharia Economic (PengantarEkonomi Syariah), Zikrul, Jakarta, 2010. 
[6] MudrajatKuncoro, MetodeRisetUntukBisnis Dan Ekonomi, Erlangga, Jakarta, 2009.

[7] Muhaimin Iqbal, Dinar Solution, Gemalnsani, Jakarta. 2008.

[8] Muhamad, MetodologiPenelitianEkonomi Islam, RajawaliPers, Jakarta. 2008.

[9] Sugiyono, MetodePenelitianBisnis, Alfa Beta, Bandung, 2008.

[10] Sukirno, Sadono, MakroEkonomiTeoriPengantar, EdisiKetiga, RajawaliPers, Jakarta, 2010

[11] Siswantoro, Dodik, KecukupanEmasUntuk Dinar Dan Rasionyadengan Dinar Dirham StudiKasus Indonesia. Journal of the Islamic Economic Forum for Indonesia Development. Vol. 1 No. Jakarta.

[12] Soeharjo, Pegadaian Syariah TakSebatasGadai, Majalah Alia, Mei 2009.

[13] YimiDiantoro, Emas, Investasi Dan Pengolahannya, Gramedia, Jakarta, 2010.

[14] YusAgusyana, Olah Data Skripsi Dan PenelitianDengan SPSS 22, Elex Media Computindo, Jakarta, 2014. 